\title{
Correction to: In search of historical roots of the extraterrestrial impact theory, Il: Two unknown German pioneers from the 1850s, Ludwig Pfeil and Karl Reichenbach
}

\author{
Grzegorz Racki $^{1} \cdot$ Christian Koeberl $^{2} \cdot$ Michał Michalak $^{1}$
}

Published online: 10 December 2021

(c) Geologische Vereinigung e.V. (GV) 2021

\author{
Correction to: \\ International Journal of Earth Sciences (2021) 110: \\ 1109-1115 \\ https://doi.org/10.1007/s00531-021-02004-0
}

Due to erroneous information in the pictorial material available on the Internet in 2019-2020, a major amendment for Fig. 1 is required. The alleged portrait of count Ludwig von Pfeil, a land-owner from Lower Silesia, actually depicts Fürst (prince) Gebhard Leberecht von Blücher (https:// www.alamy.de/fotos-bilder/prinz-bl\%C3\%BCcher.html? blackwhite=1), Prussian field marshal, a hero of the Napoleonic Wars (also related with Lower Silesia)! Fortunately, the quoted source of this image - "Illustrirte Zeitung" from 1856 - was digitized by the Österreichischen Nationalbibliothe in 2021 (https://anno.onb.ac.at/cgi-content/anno?aid= izl). Thus, we can now exhibit lithographic likeness of true Ludwig Pfeil, an unknown German pioneer of the extraterrestrial impact theory.

The original article can be found online at https://doi.org/10.1007/ s00531-021-02004-0.

Grzegorz Racki

racki@us.edu.pl

1 Faculty of Earth Sciences, University of Silesia, ul. Będzińska 60, 41-200 Sosnowiec, Poland

2 Department of Lithospheric Research, University of Vienna, Althanstrasse, 1090 Vienna, Austria 


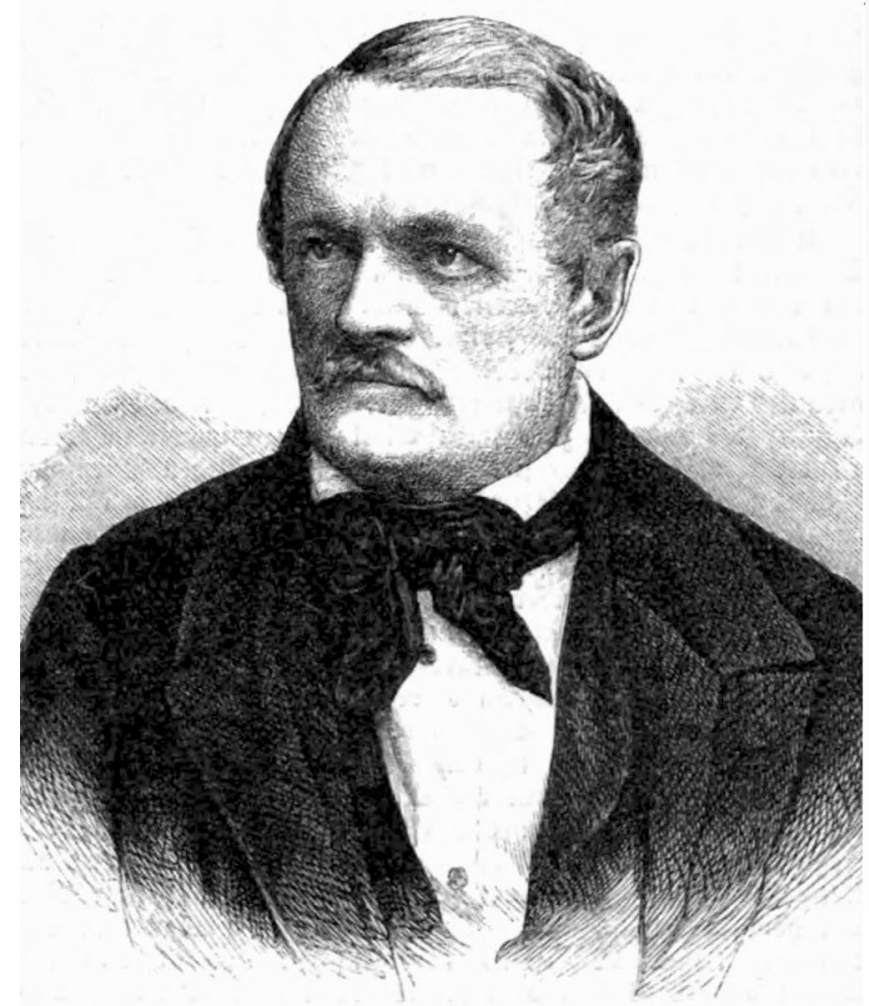

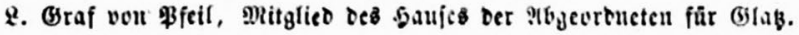

\section{Cometen und Meteore,}

bie

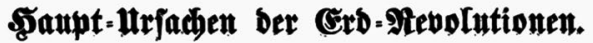

Ein Beitrag zur (Sefididite

unferer Erbe.

vou

2. Cr. won $\$$ feir.

Die befriebigenbpe Deutlibleit unb Cuibenz berriden ba, wo es mäglid twitb, bas Bejéplide auf màtbematiji beftimm.

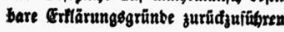

Fig. 1 Ludwig Pfeil [born in Pilgramsdorf (Pielgrzymka, Złotoryja district, modern Poland), 19 March 1803; died in Hirschberg (Jelenia Góra, modern Poland), 1 January 1896]. His full name and titles were Carl Friedrich Ludwig Fabian von Pfeil-Burghauss or von Pfeil und Klein-Ellguth, the count and laird of the land estate Lasaan (=Łażany) in Lower Silesia, hereditary member of the Prussian manor house and of the House of Representatives of the Prussian State Parliament. He was a conservative politician, publicist and naturalist (portrait from "Illustrirte Zeitung", 26, 1856, p. 412). Shown is the title page of his provocative essay from 1854 (note a motto from Alexander Humboldt's 'Kosmos') 